\title{
Short Umbilical Cord
}

National Cancer Institute

\section{Source}

National Cancer Institute. Short Umbilical Cord. NCI Thesaurus. Code C113152.

An umbilical cord at term that is less than $35 \mathrm{~cm}$ in length. 